\title{
Hydrogen storage properties of eutectic metal borohydrides melt- infiltrated into porous Al scaffolds
}

\author{
M. Veronica Sofianos, ${ }^{a, *}$ Anna-Lisa Chaudhary ${ }^{b}$, Mark Paskevicius ${ }^{a}$, Drew A. \\ Sheppard $^{a}$, Terry D. Humphries ${ }^{\text {a }}$, Martin Dornheim ${ }^{\text {b }}$, Craig E. Buckley ${ }^{a}$
}

aDepartment of Physics and Astronomy, Fuels and Energy Technology Institute, Curtin University, GPO Box U1987, Perth, WA 6845, Australia. ${ }^{b}$ Department of Nanotechnology, Institute of Materials Research, Helmholtz-Zentrum Geesthacht, D-21502 Geesthacht, Germany

*Dr Maria Veronica Sofianos

Hydrogen Storage Research Group,

Fuels and Energy Technology Institute,

Department of Physics and Astronomy

Curtin University,

GPO Box U1987,

Perth, WA 6845,

Australia.

E-mail: mvsofianou@gmail.com

Fax: +61 892662377

Tel: +61 892661534 


\section{Abstract}

Porous Al scaffolds were synthesised and melt-infiltrated with various eutectic metal borohydride mixtures $\quad\left(0.725 \mathrm{LiBH}_{4}-0.275 \mathrm{KBH}_{4}, \quad 0.68 \mathrm{NaBH}_{4}-0.32 \mathrm{KBH}_{4}, \quad 0.4 \mathrm{NaBH}_{4}-\right.$ $\left.0.6 \mathrm{Mg}\left(\mathrm{BH}_{4}\right)_{2}\right)$ to simultaneously act as both a confining framework and a reactive destabilising agent for $\mathrm{H}_{2}$ release. The scaffolds were synthesised by sintering a pellet of $\mathrm{NaAlH}_{4} / 2 \mathrm{~mol} \%$ $\mathrm{TiCl}_{3}$ at $450{ }^{\circ} \mathrm{C}$ under dynamic vacuum. During the sintering process the sodium alanate $\left(\mathrm{NaAlH}_{4}\right)$ decomposed to $\mathrm{Al}$ metal. The vacuum applied at elevated temperature promoted the $\mathrm{Na}$ metal to vaporise and be extruded from the pellet. The pores of the resulting Al scaffold were created during removal of the $\mathrm{H}_{2}$ and the $\mathrm{Na}$ from the body of the $\mathrm{NaAlH}_{4} / 2 \mathrm{~mol} \% \mathrm{TiCl}_{3}$ pellet. According to the morphological observations carried out by a Scanning Electron Microscope (SEM), melt-infiltrated eutectic mixtures of metal borohydrides were highly dispersed into the porous scaffolds. Temperature Programmed Desorption (TPD) experiments, revealed that the melt-infiltrated samples exhibited faster $\mathrm{H}_{2}$ desorption kinetics in comparison to bulk samples, with onset temperatures $\left(T_{\text {des }}\right)$ lower than the bulk by $150-250{ }^{\circ} \mathrm{C}$. The assynthesised porous Al scaffolds acted as a reactive containment vessel for these eutectic mixtures that simultaneously nanoconfined and destabilised the mixtures.

Keywords: Hydrogen storage; Destabilisation; Melt-infiltration; Porous scaffolds; Metal borohydrides; Sodium Alanate

\section{Introduction}

Energy storage is the main challenge that has to be overcome if renewable energy is to become a reliable energy source and eventually replace base-load fossil fuel power. Solid-state hydrogen storage is an efficient and cost-effective energy storage solution for stationary and mobile applications. Metal borohydrides are one of the most promising solid-state hydrogen storage materials, as they exhibit high volumetric and gravimetric hydrogen content [1-5]. 
Their high thermodynamic stability is the main disadvantage concerning technological application, resulting in high hydrogen desorption temperatures coupled with poor kinetics of hydrogen uptake and release [5-8]. Eutectic melting, reactive hydride composites or nanoconfinement are three frequently applied methods to improve the reaction kinetics or lower the hydrogen desorption temperatures of metal hydrides [9-28].

Metal borohydrides typically start desorbing hydrogen at much higher temperatures than their melting points $\left(>250{ }^{\circ} \mathrm{C}\right)$ [13]. Eutectic mixtures of these metal borohydrides result in lower melting temperatures $[11,12]$, which can increase reactivity and the kinetics of hydrogen desorption [13]. Some of these mixtures exhibit a dramatic reduction of their melting point. For example $\mathrm{LiBH}_{4}$ has a high gravimetric and volumetric hydrogen content $\left(18.5 \mathrm{wt} \% \mathrm{H}_{2}\right.$ and $121 \mathrm{~kg} \mathrm{H}_{2} / \mathrm{m}^{3}$ ) [11] and a melting point of $275{ }^{\circ} \mathrm{C}$, but only starts desorbing hydrogen above $\sim 350{ }^{\circ} \mathrm{C}$ [55]. When mixed with $\mathrm{KBH}_{4}$ to obtain the $0.725 \mathrm{LiBH}_{4}-0.275 \mathrm{KBH}_{4}$ mixture, the melting point drops to $105^{\circ} \mathrm{C}$ and hydrogen is released at $\sim 400{ }^{\circ} \mathrm{C}[11]$.

Adding a second phase such as a binary hydride, oxide, metal halide, or metal to a metal borohydride can both reduce the enthalpy of dehydrogenation and lower activation barriers, resulting in lower hydrogen desorption temperatures [4, 29-36, 65]. This method is wellestablished and has also been applied to various metal hydrides with $\mathrm{MgH}_{2}$ and $\mathrm{NaMgH}_{3}$ showing particularly promising results [37]. One of the most efficient destabilisation agents for $\mathrm{LiBH}_{4}$ is $\mathrm{Al}$. However, this system has poor hydrogen reabsorption kinetics and loss of hydrogen capacity upon cycling due to product segregation and $\mathrm{Li}_{2} \mathrm{~B}_{12} \mathrm{H}_{12}$ formation, which acts as a thermodynamic sink $[17,31,38-40]$.

Decreasing the particle size of the metal borohydrides down to the nanoscale improves their reaction kinetics as the hydrogen/reactant diffusion distances are reduced, and the interfacial contact area of the reactants is increased [41-51]. This can be achieved when the metal borohydrides are melt-infiltrated into a porous scaffold such as activated carbon, carbon 
aerogel, carbon black, carbon nanotubes/fibres, templated carbons, mesoporous silica, metal organic frameworks and porous metal scaffolds [52-58]. In this work, a porous metal scaffold was selected as it is oxygen-free and has a high thermal conductivity ( $250 \mathrm{Wm}^{-1} \mathrm{~K}^{-1}$ for $\left.\mathrm{Al}\right)$, compared to carbon aerogels and activated carbons that typically contain between $4 \mathrm{wt} \%$ and $14 \mathrm{wt} \%$ of oxygen and have low thermal conductivity $\left(1.7 \mathrm{Wm}^{-1} \mathrm{~K}^{-1}\right.$ for carbon aerogels) [5961]. The selection of a porous metal scaffold aims to prevent melt-infiltrated eutectic metal borohydride mixtures from oxidising due to oxygen present on/in the scaffolds, thus reducing the hydrogen capacity loss during the thermal analysis of the samples, and to improve the reaction kinetics due to efficient thermal diffusion across the entire sample mass.

In this study, a novel approach for improving the reaction kinetics and reducing the hydrogen desorption temperatures of metal borohydrides by melt-infiltrating their eutectic mixtures into porous $\mathrm{Al}$ scaffolds is reported. $0.725 \mathrm{LiBH}_{4}-0.275 \mathrm{KBH}_{4}\left(\mathrm{~T}_{\mathrm{mp}}=105{ }^{\circ} \mathrm{C}\right)[11], 0.68 \mathrm{NaBH}_{4}-$ $0.32 \mathrm{KBH}_{4}\left(\mathrm{~T}_{\mathrm{mp}}=460{ }^{\circ} \mathrm{C}\right)[9]$ and $0.4 \mathrm{NaBH}_{4}-0.6 \mathrm{Mg}\left(\mathrm{BH}_{4}\right)_{2}\left(\mathrm{~T}_{\mathrm{mp}}=205^{\circ} \mathrm{C}\right)[10]$ mixtures were melt-infiltrated into the scaffolds to obtain metal borohydride Al composites as the final product.

\section{Materials and methods}

\subsection{Sample preparation}

Chemicals used for the synthesis were sensitive to both air and moisture, therefore all sample preparation and handling was performed using an Ar glovebox with $\mathrm{O}_{2}$ and $\mathrm{H}_{2} \mathrm{O}$ less than 1 ppm. $\mathrm{NaAlH}_{4}$ (Sigma Aldrich, $\geq 93 \%$ ) ball milled with 2 mol\% $\mathrm{TiCl}_{3}$ (Sigma Aldrich, $\geq 99.999$ ) was used as a starting material for the synthesis of the porous Al scaffolds. The as-prepared powder was compressed into a pellet and sintered at $450{ }^{\circ} \mathrm{C}$ under dynamic vacuum. The addition of $\mathrm{TiCl}_{3}$ allowed the decomposition of $\mathrm{NaAlH}_{4}$ to $\mathrm{Al}$ at $100{ }^{\circ} \mathrm{C}$ lower than pure $\mathrm{NaAlH}_{4}$, creating the formation of the pores inside the pellet [62]. The detailed synthesis 
method is described elsewhere $[62,57]$. In brief, $\mathrm{NaAlH}_{4}$ with added $\mathrm{TiCl}_{3}$, starts to decompose at $100{ }^{\circ} \mathrm{C}$ to $\mathrm{Al}, \mathrm{NaH}$ and $\mathrm{H}_{2}$. When $400{ }^{\circ} \mathrm{C}$ is reached, $\mathrm{NaH}$ decomposes to $\mathrm{Na}$ (molten) and $\mathrm{H}_{2}$. The molten $\mathrm{Na}$ then evaporates from the main mass of the pellet via the dynamic vacuum ( $\sim 0.001$ bar) applied during sintering and is captured in a trap placed inside the reactor, leaving behind a porous $\mathrm{Al}$ scaffold. For the eutectic mixtures, $\mathrm{LiBH}_{4}$ (Sigma Aldrich, $\geq 90 \%$ ), $\mathrm{KBH}_{4}$ (Sigma Aldrich, $\geq 98 \%$ ), $\mathrm{NaBH}_{4}$ (Sigma Aldrich, $\geq 98 \%$ ) and $\mathrm{Mg}\left(\mathrm{BH}_{4}\right)_{2}$ (Sigma Aldrich, $\geq 95 \%$ ) were used as received. The bulk $0.725 \mathrm{LiBH}_{4}-0.275 \mathrm{KBH}_{4}, 0.68 \mathrm{NaBH}_{4}-0.32 \mathrm{KBH}_{4}$ and $0.4 \mathrm{NaBH}_{4}-0.6 \mathrm{Mg}\left(\mathrm{BH}_{4}\right)_{2}$ samples were prepared by ball-milling for $120 \mathrm{~min}$ (with $2 \mathrm{~min}$ pauses every $2 \mathrm{~min}$ ) under argon at $400 \mathrm{rpm}$ using a ball to powder mass ratio of 40:1 in 316 stainless steel canisters and $10 \mathrm{~mm}$ balls.

The as-prepared eutectic mixtures were melt-infiltrated into the Al scaffolds occupying $30 \mathrm{wt} \%$ of the total sample mass. The amount the eutectic mixtures encapsulated within the Al scaffold was carefully calculated taking into account both the initial pore volume of the Al scaffold, and that sufficient metal from the scaffolds remains upon reaction with the complex metal borohydrides, maintaining the structural integrity of the scaffolds $[56,57,62]$. During the melt infiltration process, 100 bar $\mathrm{H}_{2}$ pressure was applied to prevent the decomposition of the borohydrides. All mixtures were heated to temperatures slightly over their melting point $\left(0.725 \mathrm{LiBH}_{4}-0.275 \mathrm{KBH}_{4}\right.$ at $125{ }^{\circ} \mathrm{C}, 0.68 \mathrm{NaBH}_{4}-0.32 \mathrm{KBH}_{4}$ at $480{ }^{\circ} \mathrm{C}$ and $0.4 \mathrm{NaBH}_{4}-$ $0.6 \mathrm{Mg}\left(\mathrm{BH}_{4}\right)_{2}$ at $\left.225{ }^{\circ} \mathrm{C}\right)$ with a $3{ }^{\circ} \mathrm{C} / \mathrm{min}$ heating rate and kept isothermal for $30 \mathrm{~min}$. The samples were then left to cool to room temperature under hydrogen pressure. All meltinfiltrated samples are in a pellet form. 
Table 1. Description of all samples.

\begin{tabular}{|c|c|}
\hline Description & Sample ID \\
\hline Bulk $0.725 \mathrm{LiBH}_{4}-0.275 \mathrm{KBH}_{4}$ & Bulk-LiK \\
\hline Porous $\mathrm{Al}+0.725 \mathrm{LiBH}_{4}-0.275 \mathrm{KBH}_{4}$ & Al-LiK \\
\hline Bulk $0.68 \mathrm{NaBH}_{4}-0.32 \mathrm{KBH}_{4}$ & Bulk-NaK \\
\hline Porous $\mathrm{Al}+0.68 \mathrm{NaBH}_{4}-0.32 \mathrm{KBH}_{4}$ & Al-NaK \\
\hline Bulk 0.4NaBH $4-0.6 \mathrm{Mg}\left(\mathrm{BH}_{4}\right)_{2}$ & Bulk-NaMg \\
\hline Porous $\mathrm{Al}+0.4 \mathrm{NaBH}_{4}-0.6 \mathrm{Mg}\left(\mathrm{BH}_{4}\right)_{2}$ & Al-NaMg \\
\hline
\end{tabular}

\subsection{Sample characterisation}

Powder X-ray diffraction (XRD) was used for phase analysis utilising a D8 Discover (50 kV, $1000 \mathrm{~mA}$ ) with a VANTEC-500 area detector and a D8 Advance (40 kV, $40 \mathrm{~mA})$. Both diffractometers were from Bruker, Germany with a $\mathrm{CuK}_{\alpha}$ radiation. The measured $2 \theta$ range $\left(15^{\circ}-80^{\circ}\right)$ was scanned using a $0.03^{\circ}$ step size at $1.6 \mathrm{~s} / \mathrm{step}$, a rotational speed of $30 \mathrm{rpm}$ and a $0.3^{\circ}$ divergence slit in flat plate geometry. Low background Si wafer XRD sample holders were covered with a poly(methylmethacrylate) (PMMA) airtight hemispherical dome to prevent oxygen/moisture contamination during data collection. The PMMA results in a broad hump in XRD patterns centred at $2 \theta \simeq 20^{\circ}$. All XRD patterns of the melt-infiltrated samples after their thermal analysis were obtained after crushing the samples into a powder.

Morphological observations were carried out with a Zeiss Neon 40EsB (Zeiss, Germany) scanning electron microscope (SEM). Specimens were prepared by placing an extracted piece (from the inner centre) of the pellet onto carbon tape before coating them with a $3 \mathrm{~nm}$ layer of platinum to produce a conductive layer and reduce charging during SEM data collection. The exposure of the samples to air was minimised by using a custom-made ante chamber in which 
the specimens were transferred from the glovebox to the coating instrument and then to the SEM chamber.

Temperature Programmed Desorption (TPD) measurements were undertaken on a computer controlled Sieverts/volumetric apparatus [37]. The sample temperature and pressure was recorded every $30 \mathrm{~s}$ using a K-type thermocouple with a calibrated accuracy of $\pm 1{ }^{\circ} \mathrm{C}$ at 419 ${ }^{\circ} \mathrm{C}$ and a digital pressure transducer (Rosemount 3051S) with a precision/accuracy of 14 mbar. Hydrogen desorption data was obtained in the temperature range from room temperature to $550{ }^{\circ} \mathrm{C}$ with a ramping rate of $5{ }^{\circ} \mathrm{C} / \mathrm{min}$. The temperature was then kept isothermal at $550{ }^{\circ} \mathrm{C}$ for 4 hours. All TPD experiments were undertaken starting from vacuum and it is assumed that all released gas is hydrogen.

\section{Results and discussion}

\subsection{Initial phase analysis}

The X-ray diffraction patterns of all bulk eutectic metal borohydrides mixtures and meltinfiltrated porous $\mathrm{Al}$ samples are presented in Fig. 1. Diffraction peaks of $\mathrm{TiAl}_{3}$ and $\mathrm{NaCl}$ are present in all melt-infiltrated $\mathrm{Al}$ samples. These phases are due to the reaction of $\mathrm{NaAlH}_{4}$ with $\mathrm{TiCl}_{3}$ during the synthesis of the porous $\mathrm{Al}$ scaffold and are dispersed in it. The detailed synthesis method and discussion is described elsewhere [57, 62]. For bulk $0.725 \mathrm{LiBH}_{4}-$ $0.275 \mathrm{KBH}_{4}(\mathrm{Bulk}-\mathrm{LiK})$, diffraction peaks from $\mathrm{LiBH}_{4}, \mathrm{KBH}_{4}$ and the bimetallic phase $\mathrm{LiK}\left(\mathrm{BH}_{4}\right)_{2}$ are present (Fig. 1(a)). The bimetallic phase is known to spontaneously form during mixing when physical pressure is applied, either by ball milling or even by manual mixing with a mortar and pestle [11]. Upon melt-infiltration (Al-LiK), all diffraction peaks correspond to $\mathrm{Al}, \mathrm{TiAl}_{3}$, and $\mathrm{NaCl}$ and are attributed to the $\mathrm{Al}$ scaffold [62]. The lack of diffraction peaks from the borohydride compounds indicates that the eutectic mixture were successfully infiltrated into the scaffold. This phenomenon is usually pore size dependent, where small pores 
typically constrain the nanoconfined compound to being amorphous or highly nanocrystalline [63]. The XRD pattern of $0.68 \mathrm{NaBH}_{4}-0.32 \mathrm{KBH}_{4}(\mathrm{Bulk}-\mathrm{NaK})$ is shown in Fig. 1(b). Only diffraction peaks from $\mathrm{NaBH}_{4}$ and $\mathrm{KBH}_{4}$ are present in the pattern, with no formation of a solid solution evident in the sample. The solid solution of these two metal borohydrides only forms when the mixture is heat treated between $150-400{ }^{\circ} \mathrm{C}$ [9]. For the melt-infiltrated sample (Al$\mathrm{NaK}$ ), diffraction peaks of the $\mathrm{Al}$ scaffold can be observed as well as some peaks of $\mathrm{TiAl}_{3}$ and $\mathrm{NaCl}$. The same peaks are present in the XRD pattern for melt-infiltrated $0.4 \mathrm{NaBH}_{4}$ $0.6 \mathrm{Mg}\left(\mathrm{BH}_{4}\right)_{2}(\mathrm{Al}-\mathrm{NaMg})$ (Fig. 1(c)). For the bulk sample (Bulk-NaMg) only $\mathrm{NaBH}_{4}$ and $\mathrm{Mg}\left(\mathrm{BH}_{4}\right)_{2}$ are evident in the pattern.

Fig. 1: XRD patterns of (a) bulk $0.725 \mathrm{LiBH}_{4}-0.275 \mathrm{KBH}_{4}(\mathrm{Bulk}-\mathrm{LiK})$ and porous $\mathrm{Al}+$ $0.725 \mathrm{LiBH}_{4}-0.275 \mathrm{KBH}_{4}(\mathrm{Al}-\mathrm{LiK})$, (b) bulk $0.68 \mathrm{NaBH}_{4}-0.32 \mathrm{KBH}_{4}(\mathrm{Bulk}-\mathrm{NaK})$ and porous $\mathrm{Al}$ $+0.68 \mathrm{NaBH}_{4}-0.32 \mathrm{KBH}_{4}(\mathrm{Al}-\mathrm{NaK})$, (c) bulk $0.4 \mathrm{NaBH}_{4}-0.6 \mathrm{Mg}\left(\mathrm{BH}_{4}\right)_{2}(\mathrm{Bulk}-\mathrm{NaMg})$ and porous $\mathrm{Al}+0.4 \mathrm{NaBH}_{4}-0.6 \mathrm{Mg}\left(\mathrm{BH}_{4}\right)_{2}(\mathrm{Al}-\mathrm{NaMg})$. The PMMA dome of the sample holder results in a broad hump in XRD patterns centred at $\sim 20^{\circ} 2 \theta$. All melt-infiltrated samples are in a pellet form.

\subsection{Morphological observations of samples}

Fig. 2 shows the SEM micrographs of the porous Al scaffold (Fig. 2(a, b)) and the infiltrated samples with $\sim 30 \mathrm{wt} \%$ of $0.725 \mathrm{LiBH}_{4}-0.275 \mathrm{KBH}_{4}$ (Bulk-LiK) (Fig. 2 (c, d)), $0.68 \mathrm{NaBH}_{4}-$ $0.32 \mathrm{KBH}_{4}\left(\right.$ Bulk-NaK) (Fig. 2(e, f)), and 0.4NaBH $4-0.6 \mathrm{Mg}\left(\mathrm{BH}_{4}\right)_{2}($ Bulk-NaMg) (Fig.2 (g,h)). During the sintering process of the scaffold, the $\mathrm{NaAlH}_{4} / 2 \mathrm{~mol} \% \mathrm{TiCl}_{3}$ pellet decomposed to Al metal predominantly and some $\mathrm{TiAl}_{3}$. Vacuum and high temperature $\left(450{ }^{\circ} \mathrm{C}\right)$ was used to vaporise and extract $\mathrm{Na}$ leaving porous $\mathrm{Al}$ with some localised bulk $\mathrm{Al}$ areas. The pores have a broad range of sizes, with the majority of them being macropores, forming an open network with thin interconnecting walls (Fig. $1(\mathrm{a}, \mathrm{b}))$ as analytically described in our previous studies $[57,62]$. This combination of characteristics make it an ideal scaffold for melt-infiltrating metal hydrides. The metal hydrides can occupy the total pore volume of the scaffold due to the open network of pores, and the $\mathrm{H}_{2}$ can diffuse easier through the pores during thermal decomposition. In Fig. 2 (c-h) the melt-infiltrated Al scaffolds are presented, showing the successful infiltration process. The eutectic mixtures filled the entirety of the pore volume via capillary condensation creating a solid pellet. 


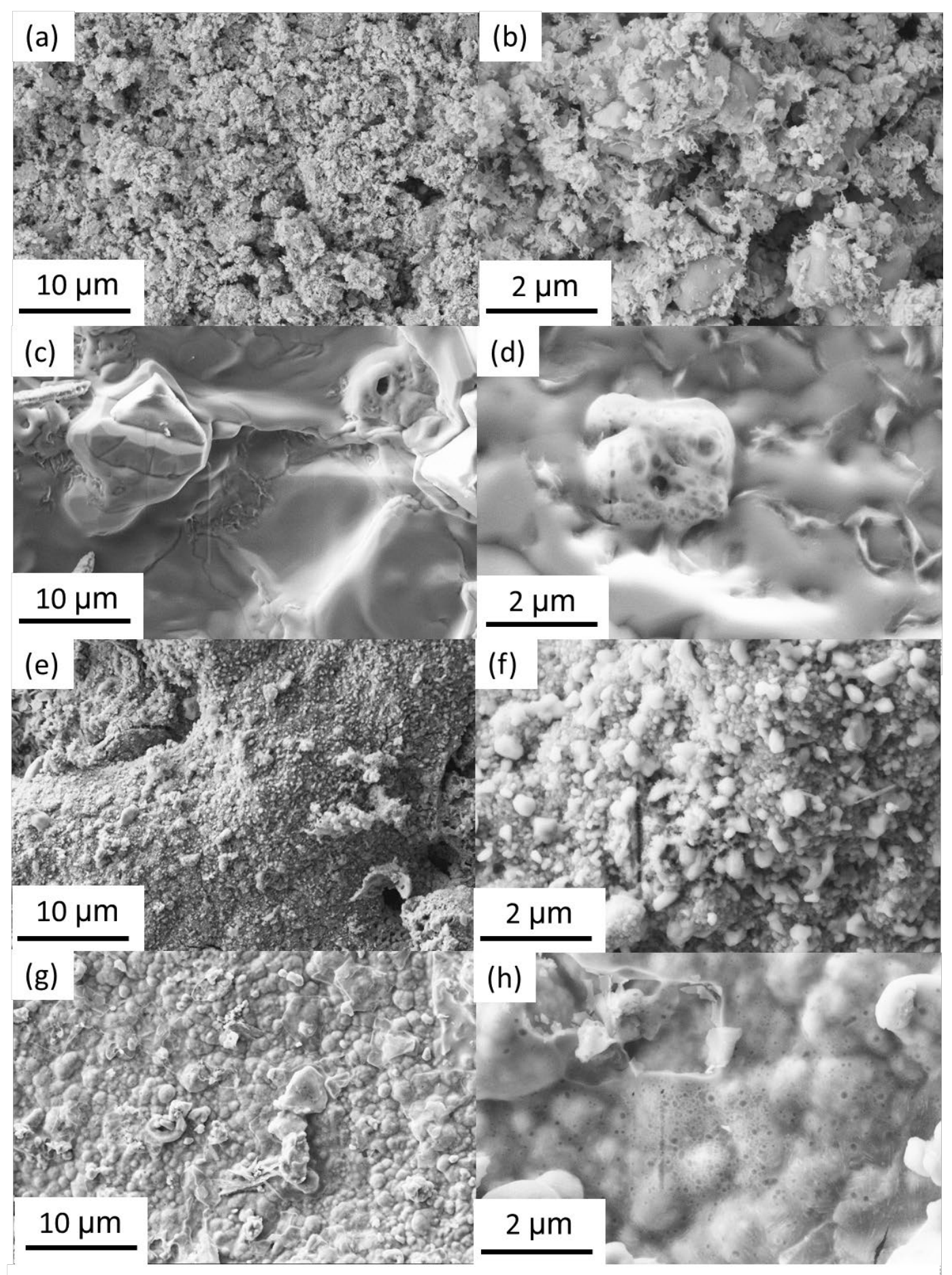

Fig. 2. SEM micrographs of the (a, b) porous $\mathrm{Al}$ scaffold, $(\mathrm{c}, \mathrm{d})$ porous $\mathrm{Al}+0.725 \mathrm{LiBH}_{4}-$ $0.275 \mathrm{KBH}_{4}(\mathrm{Al}-\mathrm{LiK}),(\mathrm{e}, \mathrm{f})$ porous $\mathrm{Al}+0.68 \mathrm{NaBH}_{4}-0.32 \mathrm{KBH}_{4}(\mathrm{Al}-\mathrm{NaK})$, and $(\mathrm{g}, \mathrm{h})$ porous $\mathrm{Al}$ $+0.4 \mathrm{NaBH}_{4}-0.6 \mathrm{Mg}\left(\mathrm{BH}_{4}\right)_{2}(\mathrm{Al}-\mathrm{NaMg})$. 


\subsection{Thermal analysis}

The TPD curves of the bulk and melt-infiltrated eutectic mixtures are presented in Fig. 3. The $\mathrm{H}_{2}$ capacity for all samples has been normalised to the desorbed $\mathrm{H}_{2}$ amount for results to be easily comparable (wt\% is reported in Table 2). In Fig 3(a), the hydrogen desorption profiles of bulk (Bulk-LiK) and melt-infiltrated (Al-LiK) $0.725 \mathrm{LiBH}_{4}-0.275 \mathrm{KBH}_{4}$ are presented. Both samples start releasing hydrogen at $\sim 100{ }^{\circ} \mathrm{C}$. It is known from the literature that the $0.725 \mathrm{LiBH}_{4}-0.275 \mathrm{KBH}_{4}$ eutectic mixture has a melting point of $105{ }^{\circ} \mathrm{C}$ at which the gradual onset of hydrogen desorption ensues. The $\operatorname{LiK}\left(\mathrm{BH}_{4}\right)_{2}$ bimetallic phase decomposes to the reactants $\left(\mathrm{LiBH}_{4}\right.$ and $\left.\mathrm{KBH}_{4}\right)$ upon heating. Thus, a rapid increase of the hydrogen desorption

rate is noticeable at $\sim 350{ }^{\circ} \mathrm{C}$, where $\mathrm{LiBH}_{4}$ melts and starts releasing hydrogen. $\mathrm{KBH}_{4}$ only starts to desorb hydrogen upon melting at $606^{\circ} \mathrm{C}[11,13]$. Hence, the XRD patterns of both samples after their thermal analysis (Fig. 4(a)) show diffraction peaks from $\mathrm{KBH}_{4}$, whereas $\mathrm{LiBH}_{4}$ has decomposed to $\mathrm{LiH}$ and $\mathrm{AlB}_{2}$. The $\mathrm{KBH}_{4}$ originates from the decomposition of bimetallic $\mathrm{LiK}\left(\mathrm{BH}_{4}\right)_{2}$ and only a small amount has decomposed to $\mathrm{KH}$ as the samples were heated below its melting point $\left(\sim 600{ }^{\circ} \mathrm{C}\right)$. This also explains why the experimental values of their desorbed $\mathrm{H}_{2} \mathrm{wt} \%$ (7.6 for Bulk-LiK, 2.2 for Al-LiK) are below the theoretical ones (13.2 for Bulk-LiK, 3.9 for Al-LiK) (Table 2). It is noticeable that both samples exhibit the same reaction kinetics and have desorbed their total amount of hydrogen after the first two hours of desorption, at which point the final temperature has been reached $\left(500{ }^{\circ} \mathrm{C}\right)$. For this particular eutectic metal borohydride mixture, the presence of the Al scaffold did not influence the onset temperature of the hydrogen desorption or the reaction kinetics.

Fig. 3(b) shows the hydrogen desorption profile of bulk (Bulk-NaK) and melt-infiltrated (AlNaK) $0.68 \mathrm{NaBH}_{4}-0.32 \mathrm{KBH}_{4}$. The onset temperature of hydrogen desorption for the bulk sample (Bulk-NaK) is $\sim 250{ }^{\circ} \mathrm{C}$, whereas it is at $\sim 100{ }^{\circ} \mathrm{C}$ for the melt-infiltrated (Al-NaK) sample. The hydrogen desorption rate rapidly increases for the bulk sample (Bulk-NaK) at 
$\sim 480{ }^{\circ} \mathrm{C}$, which is just after the melting point of the $0.68 \mathrm{NaBH}_{4}-0.32 \mathrm{KBH}_{4}$ eutectic mixture $\left(460{ }^{\circ} \mathrm{C}\right)$ [9]. The melt-infiltrated sample (Al-NaK) shows an increase in the hydrogen desorption rate at $\sim 260{ }^{\circ} \mathrm{C}$ and $\sim 460{ }^{\circ} \mathrm{C}$. It is noticeable that the melt-infiltrated sample (Al$\mathrm{NaK}$ ) desorbs hydrogen at a lower temperature than the bulk sample (Bulk-NaK). More specifically, in the first 1.5 hours the sample has desorbed $90 \%$ of its total experimental $\mathrm{H}_{2}$ capacity (2.8 theoretical $\mathrm{wt} \% \mathrm{H}_{2}$ ). In contrast, the bulk mixture has desorbed only $40 \%$ in the same time. It is evident that the melt-infiltrated sample exhibits lower onset temperature of hydrogen desorption $\left(160{ }^{\circ} \mathrm{C}\right.$ lower than the bulk sample) and faster reaction kinetics. The $\mathrm{Al}$ scaffold partially reacted with the confined borohydride mixture in a destabilising reaction which resulted in a decrease of the hydrogen desorption temperature. In addition, the decrease in particle size of the borohydrides down to the nanoscale improved their reaction kinetics. A bimetallic solid-solution $\left(\mathrm{NaK}\left(\mathrm{BH}_{4}\right)_{2}\right)$ is formed after the thermal analysis of both samples as seen in Fig. 4(b), which is commonly observed when the eutectic mixture is heated [9]. Unreacted $\mathrm{NaBH}_{4}$ and $\mathrm{KBH}_{4}$ are present in the bulk sample (Bulk-NaK), explaining why the theoretical value of $\mathrm{H}_{2} \mathrm{wt} \%(9.4 \%)$ was not reached during the TPD experiment. The formation of $\mathrm{Na}_{\mathrm{x}} \mathrm{K}_{1-\mathrm{x}} \mathrm{H}$ and $\mathrm{AlB}_{2}$ is only observed in the melt-infiltrated sample (Al-NaK). The absence of $\mathrm{NaBH}_{4}$ and $\mathrm{KBH}_{4}$ in the Al-NaK sample, indicates that the presence of the $\mathrm{Al}$ scaffold thermodynamically destabilises the eutectic mixture, and decomposes it (I don't think that you can actually say this because you don't see NaBH4 nor KBH4 after infiltration so you can't use their absence in the post-TPD sample to conclude that the Al destabilised all of the NaBH4 and $\mathrm{KBH} 4$ that was infiltrated). Some oxides are present in the both samples, and most likely formed during the XRD measurement as the sample holders are not completely air tight.

The TPD curves of bulk (Bulk-NaMg) and melt-infiltrated (Al-NaMg) $0.4 \mathrm{NaBH}_{4}-$ $0.6 \mathrm{Mg}\left(\mathrm{BH}_{4}\right)_{2}$ are presented in Fig. 3(c). The onset temperature of hydrogen desorption for the bulk (Bulk-NaMg) is at $\sim 360{ }^{\circ} \mathrm{C}$, and $100{ }^{\circ} \mathrm{C}$ for the melt-infiltrated (Al-NaMg) sample. A 
rapid increase of hydrogen desorption rate occurs at $260^{\circ} \mathrm{C}$ for the melt-infiltrated sample (Fig. 3(c)) with overall hastened reaction kinetics in comparison to the bulk sample. The reduction in hydrogen desorption onset temperature and the faster reaction kinetics of the melt-infiltrated sample are attributed to the presence of the porous Al scaffold. The scaffold has both thermodynamically destabilised the eutectic mixture, reducing the observed onset temperature of hydrogen desorption, and improved the reaction kinetics. In Fig. 4(c) the XRD patterns of the Bulk-NaMg and Al-NaMg samples are presented. Only diffraction peaks of $\mathrm{Mg}, \mathrm{Na}_{\mathrm{x}} \mathrm{Mg}_{1^{-}}$ ${ }_{x} B_{2}$ with $(x \leq 0.2)$ [64], and $\mathrm{MgB}_{2}$ are evident in both bulk (Bulk-NaMg) and melt-infiltrated sample (Al-NaMg). The $\mathrm{MgO}$ present in the sample may have formed during the XRD measurement. Neither $\mathrm{NaBH}_{4}$ nor $\mathrm{Mg}\left(\mathrm{BH}_{4}\right)_{2}$ peaks are present in the both samples but may be in an amorphous or nanoscopic state as the experimental value of the $\mathrm{H}_{2} \mathrm{wt} \%$ ( $8.5 \%$ for Bulk$\mathrm{NaMg}, 3.1$ for $\mathrm{Al}-\mathrm{NaMg})$ is lower than the theoretical one $(13.6 \%$ for Bulk-NaMg, 4.0 for Al$\mathrm{NaMg})$. 

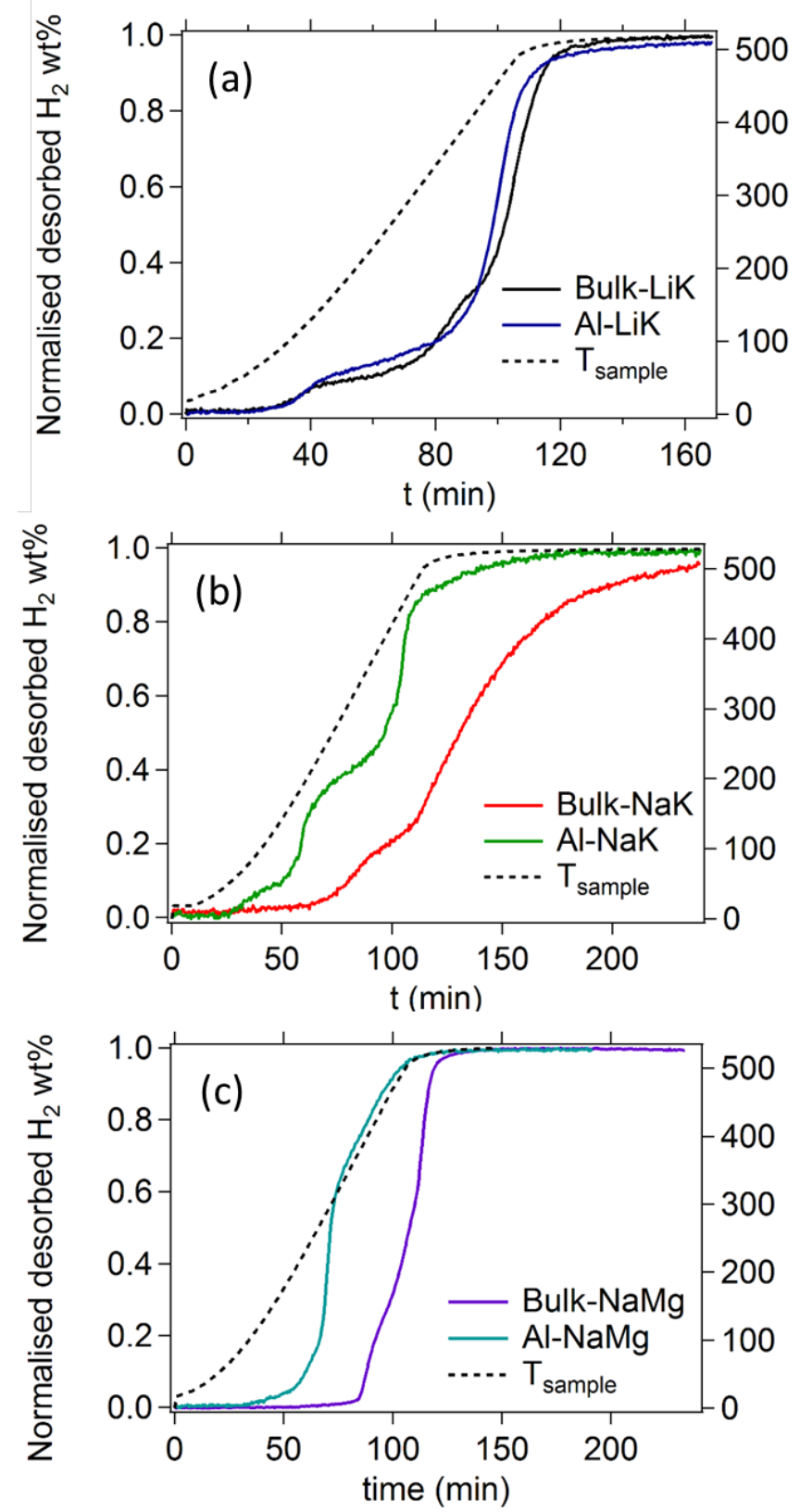

Fig. 3. Temperature programmed desorption results for (a) bulk $0.725 \mathrm{LiBH}_{4}-0.275 \mathrm{KBH}_{4}$ (Bulk-LiK) and porous $\mathrm{Al}+0.725 \mathrm{LiBH}_{4}-0.275 \mathrm{KBH}_{4}(\mathrm{Al}-\mathrm{LiK})$, (b) bulk $0.68 \mathrm{NaBH}_{4}-$ $0.32 \mathrm{KBH}_{4}(\mathrm{Bulk}-\mathrm{NaK})$ and porous $\mathrm{Al}+0.68 \mathrm{NaBH}_{4}-0.32 \mathrm{KBH}_{4}(\mathrm{Al}-\mathrm{NaK})$, (c) bulk $0.4 \mathrm{NaBH}_{4}-$ $0.6 \mathrm{Mg}\left(\mathrm{BH}_{4}\right)_{2}(\mathrm{Bulk}-\mathrm{NaMg})$ and porous $\mathrm{Al}+0.4 \mathrm{NaBH}_{4}-0.6 \mathrm{Mg}\left(\mathrm{BH}_{4}\right)_{2}(\mathrm{Al}-\mathrm{NaMg})$. 

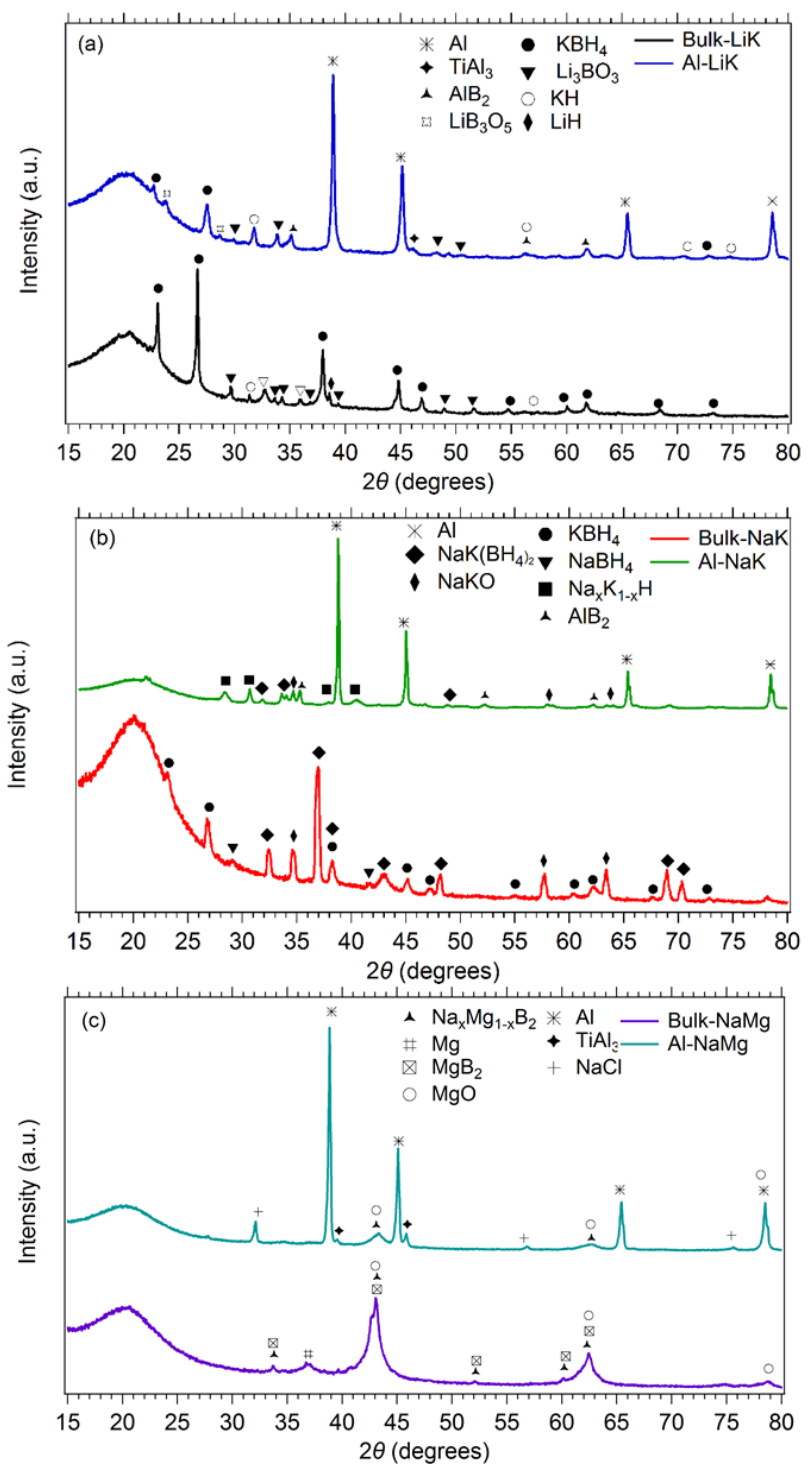

Fig. 4. XRD patterns of (a) bulk $0.725 \mathrm{LiBH}_{4}-0.275 \mathrm{KBH}_{4}(\mathrm{Bulk}-\mathrm{LiK})$ and porous $\mathrm{Al}+$ $0.725 \mathrm{LiBH}_{4}-0.275 \mathrm{KBH}_{4}(\mathrm{Al}-\mathrm{LiK})$, (b) bulk $0.68 \mathrm{NaBH}_{4}-0.32 \mathrm{KBH}_{4}(\mathrm{Bulk}-\mathrm{NaK})$ and porous $\mathrm{Al}$ $+0.68 \mathrm{NaBH}_{4}-0.32 \mathrm{KBH}_{4}(\mathrm{Al}-\mathrm{NaK})$, (c) bulk $0.4 \mathrm{NaBH}_{4}-0.6 \mathrm{Mg}\left(\mathrm{BH}_{4}\right)_{2}(\mathrm{Bulk}-\mathrm{NaMg})$ and porous $\mathrm{Al}+0.4 \mathrm{NaBH}_{4}-0.6 \mathrm{Mg}\left(\mathrm{BH}_{4}\right)_{2}(\mathrm{Al}-\mathrm{NaMg})$ after TPD experiments. The PMMA dome of the sample holder results in a broad hump in XRD patterns centred at $\sim 20^{\circ} 2 \theta$. All samples are in a powder form. 
Table 2. Experimental TPD and theoretical quantity of released $\mathrm{H}_{2}$ of the bulk (Bulk-LiK, Bulk-NaK, Bulk-NaMg) and melt-infiltrated samples (Al-LiK, Al-NaK, Al-NaMg).

\begin{tabular}{ccccc}
\hline Sample ID & $\begin{array}{c}\text { Onset } \mathrm{H}_{2} \\
\text { desorption T } \\
\left({ }^{\circ} \mathrm{C}\right)\end{array}$ & $\begin{array}{c}\text { Max } \\
\text { Pressure } \\
\text { observed } \\
(\text { bar })\end{array}$ & $\begin{array}{c}\text { Experimental } \mathrm{H}_{2} \\
\text { capacity }(\mathrm{wt} \%)\end{array}$ & $\begin{array}{c}\text { Theoretical } \mathrm{H}_{2} \\
\text { capacity }(\mathrm{wt} \%)\end{array}$ \\
\hline Bulk-LiK & 100 & 0.76 & $7.6 \pm 0.3$ & 13.2 \\
Al-LiK & 100 & 0.94 & $2.2 \pm 0.3$ & 3.9 \\
\hline Bulk-NaK & 250 & 0.49 & $4.5 \pm 0.3$ & 2.4 \\
Al-NaK & 100 & 0.40 & $1.1 \pm 0.3$ & 13.6 \\
\hline Bulk-NaMg & 360 & 0.95 & $8.5 \pm 0.3$ & 4.0 \\
Al-NaMg & 100 & 1.00 & $3.1 \pm 0.3$ & \\
\hline
\end{tabular}

\section{Conclusions}

Porous Al scaffolds were synthesised by sintering $\mathrm{NaAlH}_{4} / 0.02 \mathrm{TiCl}_{3}$ pellets under dynamic vacuum. The pores created were predominantly macropores and mesopores, as seen from the SEM micrographs. The formation of porous metal scaffolds using this cost-effective synthesis method provides the potential for these materials to be utilised not only for hydrogen storage but also in bone tissue engineering, solution separation, sensing, energy storage, and catalysis. The eutectic metal borohydride mixtures occupied the pore volume of the scaffolds during melt-infiltration, creating a solid pellet as observed by the SEM. The Temperature Programmed Desorption measurements of all samples showed that the melt-infiltrated samples started desorbing $\mathrm{H}_{2}$ at $100{ }^{\circ} \mathrm{C}$ and showed faster reaction kinetics in comparison to the bulk samples. These composite materials show promising results for mobile applications. It is believed that with the increase of mesopores in the scaffold, the surface area of $\mathrm{Al}$ in contact with the eutectic metal borohydride mixtures will be sufficient to completely destabilise the infiltrated mixtures. 
This will help to develop composite materials that desorb hydrogen predominately at temperatures below $150{ }^{\circ} \mathrm{C}$, ideal for storing hydrogen on-board in vehicles run by fuel cells. One unsuccessful attempt was made to rehydrogenate the melt-infiltrated samples at $450{ }^{\circ} \mathrm{C}$ at 100 bar of $\mathrm{H}_{2}$ backpressure. The reversibility of these samples needs to be thoroughly investigated. Strategies to consider for improving the reversibility of these hydrogen storage systems are: rehydrogenating the samples under various $\mathrm{H}_{2}$ backpressures and temperatures; adding a catalyst to the system; or creating a porous Al scaffold with a large number of mesopores and high specific surface area.

\section{Acknowledgement}

CEB, DAS, TDH and MVS acknowledge the financial support of the Australian Research Council for ARC Linkage grant LP150100730. CEB, MVS, DAS, TDH, A-LC and MD acknowledge financial support of the Australia-Germany Joint Research Cooperation Scheme DAAD (Project 57218310). DAS acknowledges the financial support of a Curtin University's Postdoctoral Research Fellowship. MP acknowledges the financial support of ARC Future Fellowship FT160100303. The authors acknowledge the facilities and technical assistance of the Microscopy \& Microanalysis Facility of the John de Laeter Centre at Curtin University. CEB acknowledges the financial support of the Australian Research Council for ARC LIEF grants LE0775551 and LE0989180 which enabled the XRD and TPD measurements to be undertaken.

\section{References}

[1] P. Javadian, S.P. GharibDoust, H.-W. Li, D.A. Sheppard, C.E. Buckley, T.R. Jensen, Reversibility of $\mathrm{LiBH}_{4}$ facilitated by the $\mathrm{LiBH}_{4}-\mathrm{Ca}\left(\mathrm{BH}_{4}\right)_{2}$ eutectic, J. Phys. Chem. C 121 (2017) 18439-18449. 
[2] L. Schlapbach, A. Züttel, Hydrogen-storage materials for mobile applications, Nature 414 (2001) 353-358.

[3] M.B. Ley, L.H. Jepsen, Y.-S. Lee, Y.W. Cho, J.M. Bellosta von Colbe, M. Dornheim, M. Rokni, J.O. Jensen, M. Sloth, Y. Filinchuk, J.E. Jørgensen, F. Besenbacher, T.R. Jensen, Complex hydrides for hydrogen storage - new perspectives, Mater. Today 17 (2014) 122-128. [4] C. Frommen, M. Sørby, M. Heere, T. Humphries, J. Olsen, B. Hauback, Rare earth borohydrides - crystal structures and thermal properties, Energies 10 (2017) 2115.

[5] J. Puszkiel, S. Garroni, C. Milanese, F. Gennari, Thomas Klassen, Martin Dornheim, Claudio Pistidda, Tetrahydroborates: development and potential as hydrogen storage medium, Inorganics 5 (2017) 1-24.

[6] S. Cahen, J.B. Eymery, R. Janot, J.M. Tarascon, Improvement of the $\mathrm{LiBH}_{4}$ hydrogen desorption by inclusion into mesoporous carbons, J. Power Sources 189 (2009) 902-908.

[7] A. Züttel, P. Wenger, S. Rentsch, P. Sudan, P. Mauron, C. Emmenegger, $\mathrm{LiBH}_{4}$ a new hydrogen storage material, J. Power Sources 118 (2003) 1-7.

[8] O. Zavorotynska, I. Saldan, S. Hino, T.D. Humphries, S. Deledda, B.C. Hauback, Hydrogen cycling in $\gamma-\mathrm{Mg}\left(\mathrm{BH}_{4}\right)_{2}$ with cobalt-based additives, J. Mater. Chem. A 3 (2015) 6592-6602.

[9] S.R.H. Jensen, L.H. Jepsen, J. Skibsted, T.R. Jensen, Phase diagram for the $\mathrm{NaBH}_{4}-\mathrm{KBH}_{4}$ system and the stability of a $\mathrm{Na}_{1-x} \mathrm{~K}_{x} \mathrm{BH}_{4}$ solid solution, J. Phys. Chem. C 119 (2015) 2791927929.

[10] M. Ley, E. Roedern, P. Thygesen, T. Jensen, Melting behavior and thermolysis of $\mathrm{NaBH}_{4}-\mathrm{Mg}\left(\mathrm{BH}_{4}\right)_{2}$ and $\mathrm{NaBH}_{4}-\mathrm{Ca}\left(\mathrm{BH}_{4}\right)_{2}$ composites, Energies 8 (2015) 2701-2713.

[11] M.B. Ley, E. Roedern, T.R. Jensen, Eutectic melting of $\mathrm{LiBH}_{4}-\mathrm{KBH}_{4}$, Phys. Chem. Chem. Phys. 16 (2014) 24194-24199.

[12] M. Paskevicius, M.B. Ley, D.A. Sheppard, T.R. Jensen, C.E. Buckley, Eutectic melting in metal borohydrides, Phys. Chem. Chem. Phys. 15 (2013) 19774-19789. 
[13] E. Roedern, B.R.S. Hansen, M.B. Ley, T.R. Jensen, Effect of eutectic melting, reactive hydride composites, and nanoconfinement on decomposition and reversibility of $\mathrm{LiBH}_{4}-$ $\mathrm{KBH}_{4}$, J. Phys. Chem. C 119 (2015) 25818-25825.

[14] H. Hagemann, V. D’Anna, J.-P. Rapin, R. Černý, Y. Filinchuk, K.C. Kim, D.S. Sholl, S.F. Parker, New fundamental experimental studies on $\alpha-\mathrm{Mg}\left(\mathrm{BH}_{4}\right)_{2}$ and other borohydrides, J. Alloys Compd. 509 (2011) S688-S690.

[15] P. Javadian, T.R. Jensen, Enhanced hydrogen reversibility of nanoconfined $\mathrm{LiBH}_{4}-$ $\mathrm{Mg}\left(\mathrm{BH}_{4}\right)_{2}$, Int. J. Hydrog. Energy 39 (2014) 9871-9876.

[16] M. Paskevicius, L.H. Jepsen, P. Schouwink, R. Cerny, D.B. Ravnsbaek, Y. Filinchuk, M. Dornheim, F. Besenbacher, T.R. Jensen, Metal borohydrides and derivatives - synthesis, structure and properties, Chem Soc Rev 46 (2017) 1565-1634.

[17] M. Heere, S.H. Payandeh GharibDoust, C. Frommen, T.D. Humphries, M.B. Ley, M.H. Sorby, T.R. Jensen, B.C. Hauback, The influence of LiH on the rehydrogenation behavior of halide free rare earth $(\mathrm{RE})$ borohydrides $(\mathrm{RE}=\mathrm{Pr}, \mathrm{Er})$, Phys. Chem. Chem. Phys. 18 (2016) 24387-24395.

[18] F. Karimi, M.V.C. Riglos, A. Santoru, A. Hoell, V.S. Raghuwanshi, C. Milanese, N. Bergemann, C. Pistidda, P. Nolis, M.D. Baro, G. Gizer, T.-T. Le, P.K. Pranzas, M. Dornheim, T. Klassen, A. Schreyer, J. Puszkiel, In situ formation of $\mathrm{TiB}_{2}$ nanoparticles for enhanced dehydrogenation/hydrogenation reaction kinetics of $\mathrm{LiBH}_{4}-\mathrm{MgH}_{2}$ as a reversible solid-state hydrogen storage composite system, J. Phys. Chem. C 122 (2018) 11671-11681.

[19] J. Jepsen, C. Milanese, J. Puszkiel, A. Girella, B. Schiavo, G. Lozano, G. Capurso, J. Bellosta von Colbe, A. Marini, S. Kabelac, M. Dornheim, T. Klassen, Fundamental material properties of the $2 \mathrm{LiBH}_{4}-\mathrm{MgH}_{2}$ reactive hydride composite for hydrogen storage: (II) kinetic properties, Energies 11 (2018) 1170. 
[20] E.M. Dematteis, A. Santoru, M.G. Poletti, C. Pistidda, T. Klassen, M. Dornheim, M. Baricco, Phase stability and hydrogen desorption in a quinary equimolar mixture of lightmetals borohydrides, Int. J. Hydrog. Energy (2018) In press, available online 29/05/2018.

[21] J. Jepsen, C. Milanese, J. Puszkiel, A. Girella, B. Schiavo, G. Lozano, G. Capurso, J. Bellosta von Colbe, A. Marini, S. Kabelac, M. Dornheim, T. Klassen, Fundamental material properties of the $2 \mathrm{LiBH}_{4}-\mathrm{MgH}_{2}$ reactive hydride composite for hydrogen storage: (I) thermodynamic and heat transfer properties, Energies 11 (2018) 1081.

[22] T.-T. Le, C. Pistidda, J. Puszkiel, M.V. Castro Riglos, F. Karimi, J. Skibsted, S.P. GharibDoust, B. Richter, T. Emmler, C. Milanese, A. Santoru, A. Hoell, M. Krumrey, E. Gericke, E. Akiba, T.R. Jensen, T. Klassen, M. Dornheim, Design of a nanometric AlTi additive for $\mathrm{MgB}_{2}$-based reactive hydride composites with superior kinetic properties, The $\mathrm{J}$. Phys. Chem. C 122 (2018) 7642-7655.

[23] J.A. Puszkiel, M.V. Castro Riglos, J.M. Ramallo-López, M. Mizrahi, F. Karimi, A. Santoru, A. Hoell, F.C. Gennari, P.A. Larochette, C. Pistidda, T. Klassen, J.M. Bellosta von Colbe, M. Dornheim, A novel catalytic route for hydrogenation-dehydrogenation of $2 \mathrm{LiH}+$ $\mathrm{MgB}_{2}$ via in situ formed core-shell $\mathrm{Li}_{\mathrm{x}} \mathrm{TiO}_{2}$ nanoparticles, J. Mater. Chem. A 5 (2017) 12922-12933.

[24] J.A. Puszkiel, M.V. Castro Riglos, F. Karimi, A. Santoru, C. Pistidda, T. Klassen, J.M. Bellosta von Colbe, M. Dornheim, Changing the dehydrogenation pathway of $\mathrm{LiBH}_{4}-\mathrm{MgH}_{2}$ via nanosized lithiated $\mathrm{TiO}_{2}$, Phys. Chem. Chem. Phys. 19 (2017) 7455-7460.

[25] J.L. Carrillo-Bucio, I. Saldan, C. Pistidda, F. Karimi, K. Suárez-Alcántara, M. Dornheim, T. Klassen, Hydrogenation study of $\mathrm{NaF} / \mathrm{NaH} / \mathrm{MgB}_{2}$ reactive hydride composites, J. Phys. Chem. C 121 (2017) 4093-4102. 
[26] G. Li, M. Matsuo, S. Takagi, A.-L. Chaudhary, T. Sato, M. Dornheim, S.-i. Orimo, Thermodynamic properties and reversible hydrogenation of $\mathrm{LiBH}_{4}-\mathrm{Mg}_{2} \mathrm{FeH}_{6}$ composite materials, Inorganics, 5 (2017) 81 .

[27] N. Busch, J. Jepsen, C. Pistidda, J.A. Puszkiel, F. Karimi, C. Milanese, M. Tolkiehn, A.L. Chaudhary, T. Klassen, M. Dornheim, Influence of milling parameters on the sorption properties of the $\mathrm{LiH}-\mathrm{MgB}_{2}$ system doped with $\mathrm{TiCl}_{3}$, J. Alloys Compd. 645 (2015) 299-303. [28] A.-L. Chaudhary, G. Li, M. Matsuo, S.-i. Orimo, S. Deledda, M.H. Sørby, B.C. Hauback, C. Pistidda, T. Klassen, M. Dornheim, Simultaneous desorption behavior of M borohydrides and $\mathrm{Mg}_{2} \mathrm{FeH}_{6}$ reactive hydride composites $(\mathrm{M}=\mathrm{Mg}$, then Li, Na, K, Ca), Appl. Phys. Lett. 107 (2015) 073905.

[29] D.A. Sheppard, L.H. Jepsen, T.R. Jensen, M. Paskevicius, C.E. Buckley, New directions for hydrogen storage: sulphur destabilised sodium aluminium hydride, J. Mater. Chem. A 1 (2013) 12775.

[30] Y. Zhou, Y. Liu, W. Wu, Y. Zhang, M. Gao, H. Pan, Improved hydrogen storage properties of $\mathrm{LiBH}_{4}$ destabilized by in situ formation of $\mathrm{MgH}_{2}$ and $\mathrm{LaH}_{3}$, J. Phys. Chem. C 116 (2012) $1588-1595$

[31] X. Yu, G. Xia, Z. Guo, H. Liu, Dehydrogenation/rehydrogenation mechanism in aluminum destabilized lithium borohydride, J. Mater. Res. 24 (2011) 2720-2727.

[32] T.E. Price, D.M. Grant, D. Weston, T. Hansen, L.M. Arnbjerg, D.B. Ravnsbaek, T.R. Jensen, G.S. Walker, The effect of $\mathrm{H}_{2}$ partial pressure on the reaction progression and reversibility of lithium-containing multicomponent destabilized hydrogen storage systems, J. Am. Chem. Soc 133 (2011) 13534-13538.

[33] J.J. Vajo, F. Mertens, C.C. Ahn, R.C. Bowman, B. Fultz, Altering hydrogen storage properties by hydride destabilization through alloy formation: $\mathrm{LiH}$ and $\mathrm{MgH}_{2}$ destabilized with Si, J. Phys. Chem. B 108 (2004) 13977-13983. 
[34] J.J. Vajo, G.L. Olson, Hydrogen storage in destabilized chemical systems, Scr. Mater. 56 (2007) 829-834.

[35] J.J. Vajo, S.L. Skeith, F. Mertens, Reversible storage of hydrogen in destabilized $\mathrm{LiBH}_{4}$, J. Phys. Chem. B 109 (2005) 3719-3722.

[36] T.D. Humphries, G.N. Kalantzopoulos, I. Llamas-Jansa, J.E. Olsen, B.C. Hauback, Reversible hydrogenation studies of $\mathrm{NaBH}_{4}$ milled with Ni-containing additives, J. Phys. Chem. C 117 (2013) 6060-6065.

[37] A.-L. Chaudhary, M. Paskevicius, D.A. Sheppard, C.E. Buckley, Thermodynamic destabilisation of $\mathrm{MgH}_{2}$ and $\mathrm{NaMgH}_{3}$ using Group IV elements $\mathrm{Si}$, Ge or Sn, J. Alloys Compd. $623(2015)$ 109-116.

[38] J.W. Kim, O. Friedrichs, J.-P. Ahn, D.H. Kim, S.C. Kim, A. Remhof, H.-S. Chung, J. Lee, J.-H. Shim, Y.W. Cho, A. Züttel, K.H. Oh, Microstructural change of $2 \mathrm{LiBH}_{4} / \mathrm{Al}$ with hydrogen sorption cycling: separation of Al and B, Scr. Mater. 60 (2009) 1089-1092.

[39] B.R.S. Hansen, D.B. Ravnsbæk, D. Reed, D. Book, C. Gundlach, J. Skibsted, T.R. Jensen, Hydrogen storage capacity loss in a $\mathrm{LiBH}_{4}-\mathrm{Al}$ Composite, J. Phys. Chem. C 117 (2013) 74237432.

[40] M. Paskevicius, M.P. Pitt, D.H. Brown, D.A. Sheppard, S. Chumphongphan, C.E. Buckley, First-order phase transition in the $\mathrm{Li}_{2} \mathrm{~B}_{12} \mathrm{H}_{12}$ system, Phys. Chem. Chem. Phys. 15 (2013) 15825-15828.

[41] P. Adelhelm, P.E. de Jongh, The impact of carbon materials on the hydrogen storage properties of light metal hydrides, J. Mater. Chemi. 21 (2011) 2417-2427.

[42] P. Javadian, D. Sheppard, C. Buckley, T. Jensen, Hydrogen desorption properties of bulk and nanoconfined $\mathrm{LiBH}_{4}-\mathrm{NaAlH}_{4}$, Crystals 6 (2016) 70. 
[43] M. Paskevicius, H.-Y. Tian, D.A. Sheppard, C.J. Webb, M.P. Pitt, E.M. Gray, N.M. Kirby, C.E. Buckley, Magnesium hydride formation within carbon aerogel, J. Phys. Chem. C 115 (2011) 1757-1766.

[44] M. Paskevicius, D.A. Sheppard, C.E. Buckley, Thermodynamic changes in mechanochemically synthesized magnesium hydride nanoparticles, J. Am. Chem. Soc. 132 (2010) 5077-5083.

[45] S. Chumphongphan, U. Filsø, M. Paskevicius, D.A. Sheppard, T.R. Jensen, C.E. Buckley, Nanoconfinement degradation in $\mathrm{NaAlH}_{4} / \mathrm{CMK}-1$, Int. J. Hydrog. Energy 39 (2014) 1110311109.

[46] E. Callini, P.Á. Szilágyi, M. Paskevicius, N.P. Stadie, J. Réhault, C.E. Buckley, A. Borgschulte, A. Züttel, Stabilization of volatile $\mathrm{Ti}\left(\mathrm{BH}_{4}\right)_{3}$ by nano-confinement in a metalorganic framework, Chem. Sci. 7 (2016) 666-672.

[47] H.Y. Tian, C.E. Buckley, M. Paskevicius, D.A. Sheppard, Hydrogen Storage in Carbon Aerogels, Pan Stanford Publishing, 2012.

[48] A. Surrey, C. Bonatto Minella, N. Fechler, M. Antonietti, H.-J. Grafe, L. Schultz, B. Rellinghaus, Improved hydrogen storage properties of LiBH4 via nanoconfinement in microand mesoporous aerogel-like carbon, Int. J. Hydrog. Energy 41 (2016) 5540-5548.

[49] J. Shao, X. Xiao, X. Fan, X. Huang, B. Zhai, S. Li, H. Ge, Q. Wang, L. Chen, Enhanced hydrogen storage capacity and reversibility of $\mathrm{LiBH}_{4}$ nanoconfined in the densified zeolitetemplated carbon with high mechanical stability, Nano Energy 15 (2015) 244-255.

[50] S. Thiangviriya, R. Utke, $\mathrm{LiBH}_{4}$ nanoconfined in activated carbon nanofiber for reversible hydrogen storage, Inter. J. Hydrogen Energy 40 (2015) 4167-4174.

[51] J. Gao, P. Ngene, I. Lindemann, O. Gutfleisch, K.P. de Jong, P.E. de Jongh, Enhanced reversibility of $\mathrm{H}_{2}$ sorption in nanoconfined complex metal hydrides by alkali metal addition, J. Mater. Chem. 22 (2012) 13209. 
[52] R. Gosalawit-Utke, C. Milanese, P. Javadian, A. Girella, D. Laipple, J. Puszkiel, A.S. Cattaneo, C. Ferrara, J. Wittayakhun, J. Skibsted, T.R. Jensen, A. Marini, T. Klassen, M. Dornheim, $2 \mathrm{LiBH}_{4}-\mathrm{MgH}_{2}-0.13 \mathrm{TiCl}_{4}$ confined in nanoporous structure of carbon aerogel scaffold for reversible hydrogen storage, J. Alloys Compd. 599 (2014) 78-86.

[53] A.F. Gross, J.J. Vajo, S.L. Van Atta, G.L. Olson, Enhanced hydrogen storage kinetics of $\mathrm{LiBH}_{4}$ in nanoporous carbon scaffolds, J. Phys. Chem. C 112 (2008) 5651-5657.

[54] T.K. Nielsen, M. Polanski, D. Zasada, P. Javadian, F. Besenbacher, J. Bystrzycki, J. Skibsted, T.R. Jensen, Improved hydrogen storage kinetics of nanoconfined $\mathrm{NaAlH}_{4}$ catalyzed with $\mathrm{TiCl}_{3}$ nanoparticles, ACS Nano 5 (2011) 4056-4064.

[55] M.V. Sofianos, D.A. Sheppard, M.R. Rowles, T.D. Humphries, S. Liu, C.E. Buckley, Novel synthesis of porous $\mathrm{Mg}$ scaffold as a reactive containment vessel for $\mathrm{LiBH}_{4}, \mathrm{RSC}$ Advances 7 (2017) 36340-36350.

[56] M.V. Sofianos, D.A. Sheppard, D.S. Silvester, J. Lee, M. Paskevicius, T.D. Humphries, C.E. Buckley, Electrochemical synthesis of highly ordered porous Al scaffolds melt-infiltrated with $\mathrm{LiBH}_{4}$ for hydrogen storage, J. Electrochem. Soc. 165 (2018) D37-D42.

[57] M.V. Sofianos, D.A. Sheppard, E. Ianni, T.D. Humphries, M.R. Rowles, S. Liu, C.E. Buckley, Novel synthesis of porous aluminium and its application in hydrogen storage, J. Alloys Compd. 702 (2017) 309-317.

[58] E. Callini, P.A. Szilagyi, M. Paskevicius, N.P. Stadie, J. Rehault, C.E. Buckley, A. Borgschulte, A. Zuttel, Stabilization of volatile $\mathrm{Ti}\left(\mathrm{BH}_{4}\right)_{3}$ by nano-confinement in a metalorganic framework, Chem Sci 7 (2016) 666-672.

[59] S.A. Al-Muhtaseb, J.A. Ritter, Preparation and properties of resorcinol-formaldehyde organic and carbon gels, Adv. Mater. 15 (2003) 101-114.

[60] H.P. Boehm, Some aspects of the surface chemistry of carbon blacks and other carbons, Carbon, 32 (1994) 759-769. 
[61] R. Fu, B. Zheng, J. Liu, S. Weiss, J.Y. Ying, M.S. Dresselhaus, G. Dresselhaus, J. Satcher, T. Baumann, Studies of the chemical and pore structures of the carbon aerogels synthesized by gelation and supercritical drying in isopropanol, J. Appl. Polym. Sci. 91 (2004) 3060-3067.

[62] E. Ianni, M.V. Sofianos, D.A. Sheppard, M.R. Rowles, T.D. Humphries, S. Liu, C.E. Buckley, Synthesis and characterisation of a porous Al scaffold sintered from $\mathrm{NaAlH}_{4}, \mathrm{~J}$. Mater. Sci. 53 (2017) 1076-1087.

[63] S. Cahen, J.B. Eymery, R. Janot, J.M. Tarascon, Improvement of the $\mathrm{LiBH}_{4}$ hydrogen desorption by inclusion into mesoporous carbons, J. Power Sources 189 (2009) 902-908.

[64] S.Y. Li, Y.M. Xiong, W.Q. Mo, R. Fan, C.H. Wang, X.G. Luo, Z. Sun, H.T. Zhang, L. Li, L.Z. Cao, X.H. Chen, Alkali metal substitution effects in $\mathrm{Mg}_{1-\mathrm{x}} \mathrm{A}_{\mathrm{x}} \mathrm{B}_{2}(\mathrm{~A}=\mathrm{Li}$ and $\mathrm{Na})$, Physics C 363 (2001) 219-223.

[65] E. Ianni, M.V. Sofianos, M.R. Rowles, D.A. Sheppard, T.D. Humphries, C.E. Buckley, Synthesis of $\mathrm{NaAlH}_{4} / \mathrm{Al}$ composites and their applications in hydrogen storage, Inter. J. Hydrogen Energy 43 (2018) 17309-17317. 